\title{
The historic data series on AIDS in the state of Ceará, Brazil
}

\author{
Nathália Lima Pedrosa ${ }^{1}$ \\ Simone de Sousa Paiva ${ }^{2}$ \\ Rosa Lívia Freitas de Almeida ${ }^{3}$ \\ Eliane Rolim de Holanda ${ }^{4}$ \\ Ligia Regina Franco Sansigolo Kerr ${ }^{3}$ \\ Marli Teresinha Gimeniz Galvão ${ }^{1}$
}

\footnotetext{
${ }^{1}$ Departamento de Enfermagem, Centro de Ciências da Saúde, Universidade Federal do Ceará. R. Alexandre Baraúna 1115, Rodolfo Teófilo. 60430-160 Fortaleza CE Brasil.nati.ufc@gmail.com ${ }^{2}$ Prefeitura Municipal de Fortaleza.

${ }^{3}$ Departamento de Saúde Coletiva, Centro de Ciências da Saúde, Universidade Federal do Ceará.

${ }^{4}$ Universidade Federal de Pernambuco.
}

\begin{abstract}
This study describes the historic records on AIDS in the Brazilian state of Ceará, with analysis by gender, age group and race. It is a descriptive, retrospective, ecological study, analyzing 7,896 notifications of cases of AIDS, of people aged 13 and above, resident in the Ceará, over the period 2001 through 2011. Percentage occurrences and other data were calculated based on the variables gender, age group and race. Average and comparison tests were made, considering $p$ $<0.05$ and the trend line. There is a progressive increase in the number of cases. The majority of cases are in men. The ratio between the sexes falls from 2003 through 2007, but the number of women is still lower overall in the period. Higher rates of occurrence were found between the ages of 30 and 39, and of those with black-white mixed-race skin color (80\%). Based on the variables studied in the series that was analyzed, the results indicate a need for differentiated strategies in prevention and control of the disease in the state.
\end{abstract}

Key words Acquired immune deficiency syndrome, Epidemiology, Epidemiological monitoring 


\section{Introduction}

The world response to AIDS has achieved significant gains in terms of prevention and treatment. There continues to be a strong global effort to reach targets, aiming for zero occurrence of new infections, elimination of the stigma related to HIV all over the world, and considerable reduction in the number of deaths related to the disease ${ }^{1}$.

After 30 years of the disease in Brazil, there is an increase in survival time of people with HIV/ AIDS, in detriment to the high degree of lethality when the epidemic started. Knowledge of the epidemiology of HIV/AIDS in Brazil is fundamental for an understanding of this recent dynamic, providing support in the strategies of prevention and treatment, as well as evaluation of the impact of universal therapy ${ }^{2}$.

It is found that numbers of cases of AIDS are increasing among females, younger people, people from the interior of the state, and poorer people. As a result, to achieve the global targets that have been established requires a new look at the epidemiological patterns that emerge in the context of AIDS, to establish health intervention actions that are effective in control of the disease.

In Brazil, more than 39,185 cases of the disease were recorded in 2012 - or 20.2 cases of AIDS per 100,000 people in the country. Approximately 253,000 deaths in the country were related to AIDS, concentrated in the Southeastern region, which had $56 \%$ of the total accumulated number of cases. Over the years 2003 through 2012, the number of cases detected annually in the Northeastern Region of Brazil increased by $62.6 \%$, while in the same period it decreased by $18.6 \%$ in the Southeastern Region, and $0.3 \%$ in the South ${ }^{3}$.

Approximately 800 cases of AIDS were notified in Ceará, in 2012, of which 53.7\% were of people living in the state's capital city, Fortaleza. Since the first records were made of the disease, in the 1980s, a total of 12,246 cases were recorded up to the year $2012,70 \%$ of them in males ${ }^{4}$. In terms of distribution in the interior of the state, $96 \%$ of the municipalities of Ceará have had at least one case of AIDS. However, sub-notification may be the factor responsible for there being some municipalities that have not yet reported once case of the disease.

Ceará is in a region that has severe disparities in relation to AIDS. In a study on the spread of mortality from the disease in Brazil from 1998 through 2008, it was found to have expanded in the Northeast and North, while declining in the rest of the country, principally in the Southeast - indicating that apparent overall stability of the figures for mortality from AIDS in the country masks regional differences 5 .

To establish significant strategies for reducing the risk and vulnerability of individuals and communities, a broad understanding of the regional reality is essential. This understanding becomes an instrument for transformation of the environment where one lives, through adaptation of the current public policies in the context of local epidemiology, strengthening of community capacities, and stimulus to creation of social networks of support for vulnerable people.

This study has all this in mind while describing the historic series of data on AIDS in Ceará in relation to gender, age group and race, over the years 2001-2011.

\section{Methods}

This was an ecological, descriptive, retrospective study constituted on the basis of analyses of time series for the rate of occurrence of AIDS in the state of Ceará, for the period 2001 through 2011. Cases of AIDS that had been notified on the compulsory Notification Report of the Reports Notification Information System (Sistema de Informação de Agravos de Notificação, or Sinan), obtained from the State Health Department of the State of Ceará (SESA), were studied.

The category adopted for inclusion was: cases of AIDS in people aged 13 or over, resident in the state of Ceará, notified over the years 2001 through 2011.

A total of 8,003 notifications of cases of AIDS were collected; 38 of these were found to be duplications, and 69 were for people living outside the state. Thus, 107 were excluded, resulting in a total universe of 7,896 cases for the study.

The rate of occurrence was calculated, by gender and by age group (13-19; 20-24; 25-29; $30-34$; 35-39; 40-49; 50-59; and over 60), per 100,000 (using the estimated population of the state for each year). Percentages of cases of AIDS, by race, and their rates of change, by gender and age group, for the period, were also calculated.

The categorical variables were described by proportional frequency distribution, and tests were applied for comparison of proportions (Fisher's exact test or the Pearson chi-squared test) and for comparison of averages (Student's t-test). All adopted alpha below 0.05 as necessary 
for rejection of the null hypothesis. The predetermined $\mathrm{p}$-value was 0.05 . The trend analysis was established using Pearson's R test, and all the data distribution functions were tested. Version 20.0 of the Statistical Package for Social Sciences (SPSS) program was used.

The study was approved by the Research Ethics Committee of SESA.

\section{Results}

Of the 7,896 cases of AIDS, over the period 20012011 , there was fast growth in rates of occurrence among individuals aged 13 or over, seen in the trend line with potential adjustment, with $\mathrm{R}^{2}=$ 0.397 (Graphic 1). In 2001, this rate was 7.69 cases of AIDS per 100,000 population, and in 2011 it was 14.14; there were however oscillations between 2004 and 2011, with a fall in the years 2005-7 (from 10.59 to 8.16 cases per 100,000 population), and with a maximum of 15.48 in 2010 .

In relation to gender, the majority of the notifications of AIDS in the state of Ceará over the period were males - increasing from 11.01 cases per 100,000 population in 2001 to 20.7 in 2011 . (Graphic 2). Here, too, there were fluctuations in rates of occurrence, with peaks in the even-num- ber years 2004, 2006 and 2010, and adjustment following a polynomial trend $\left(\mathrm{R}^{2}=0.6317\right)$.

In the female population, cases of AIDS increased from 4.62 per 100,000 population, in 2001 , to 8.06 per 100,000 in 2011 . There was fast growth in the period studied, with adjustment of the potential trend line $\left(\mathrm{R}^{2}=0.577\right)$. In the period 2003-7, there was a fall in the ratio between the sexes, with the proportions varying from 2.4 to 1.8. Even so, women continued to have the lower percentage incidence. There was one case in which the gender was unknown (Graphic 2).

The average age in the diagnosis of cases of AIDS was 36.3 for males and 34.8 for females. The average age for diagnosis in men is statistically higher $(\mathrm{p}<0.01)$ than that of women, suggesting that diagnosis of AIDS in the male population occurs later (Table 1).

In the consideration by age group: Rates of occurrence of the disease showed an upward trend in all the age ranges. (Table 1). There was a rapid increase, adjusted to the potential trend line, in the age ranges 30-34, 35-39, 40-49 and 60 years (with R2 $=0.310,0.250,0.360$ and 0.476 , respectively). There was an adjusted rise in the polynomial trendline in the age range 13-19, with a peak in the years 2003, 2005 and 2009, presenting the highest R2 of all the age groups (0.646).

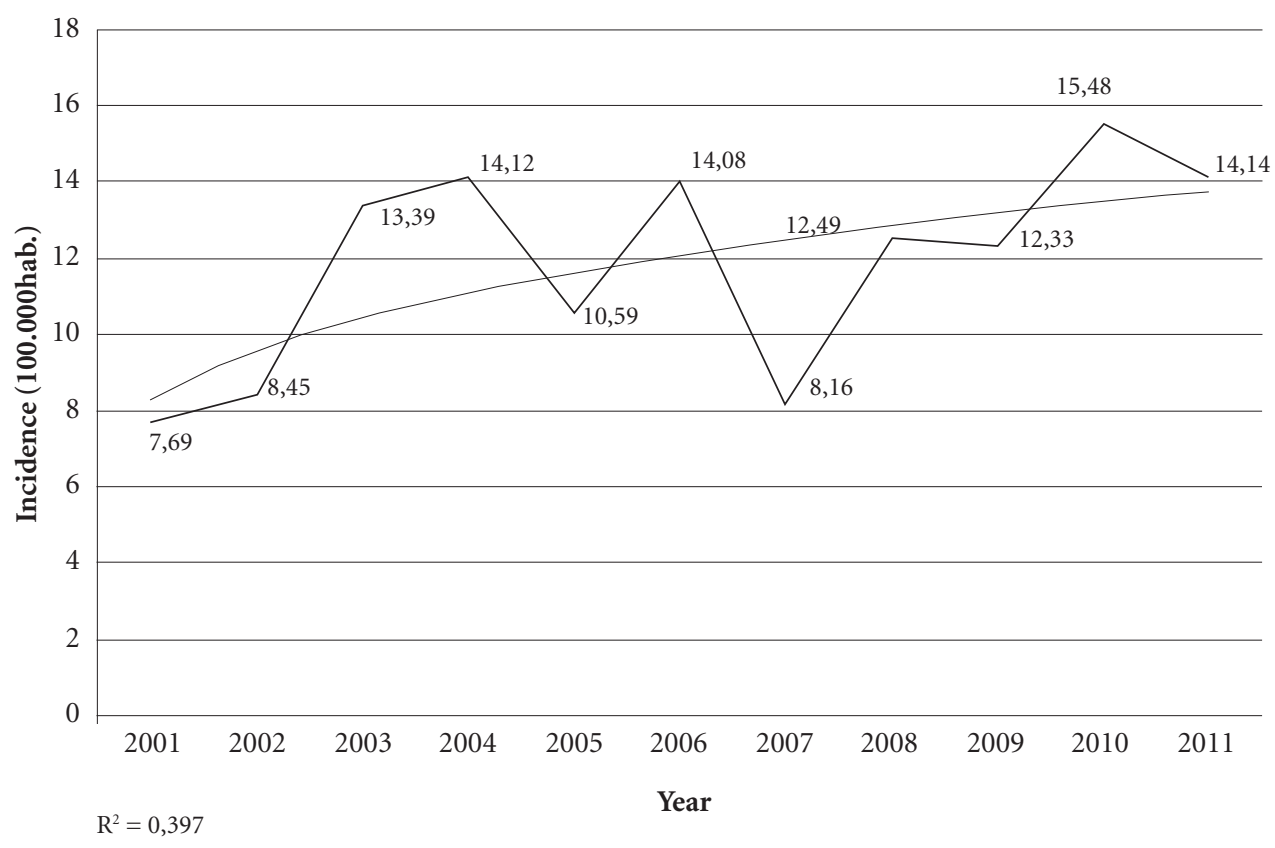

Graph 1. Incidence rate of AIDS by year, Ceará, Brazil, 2001-2011. 


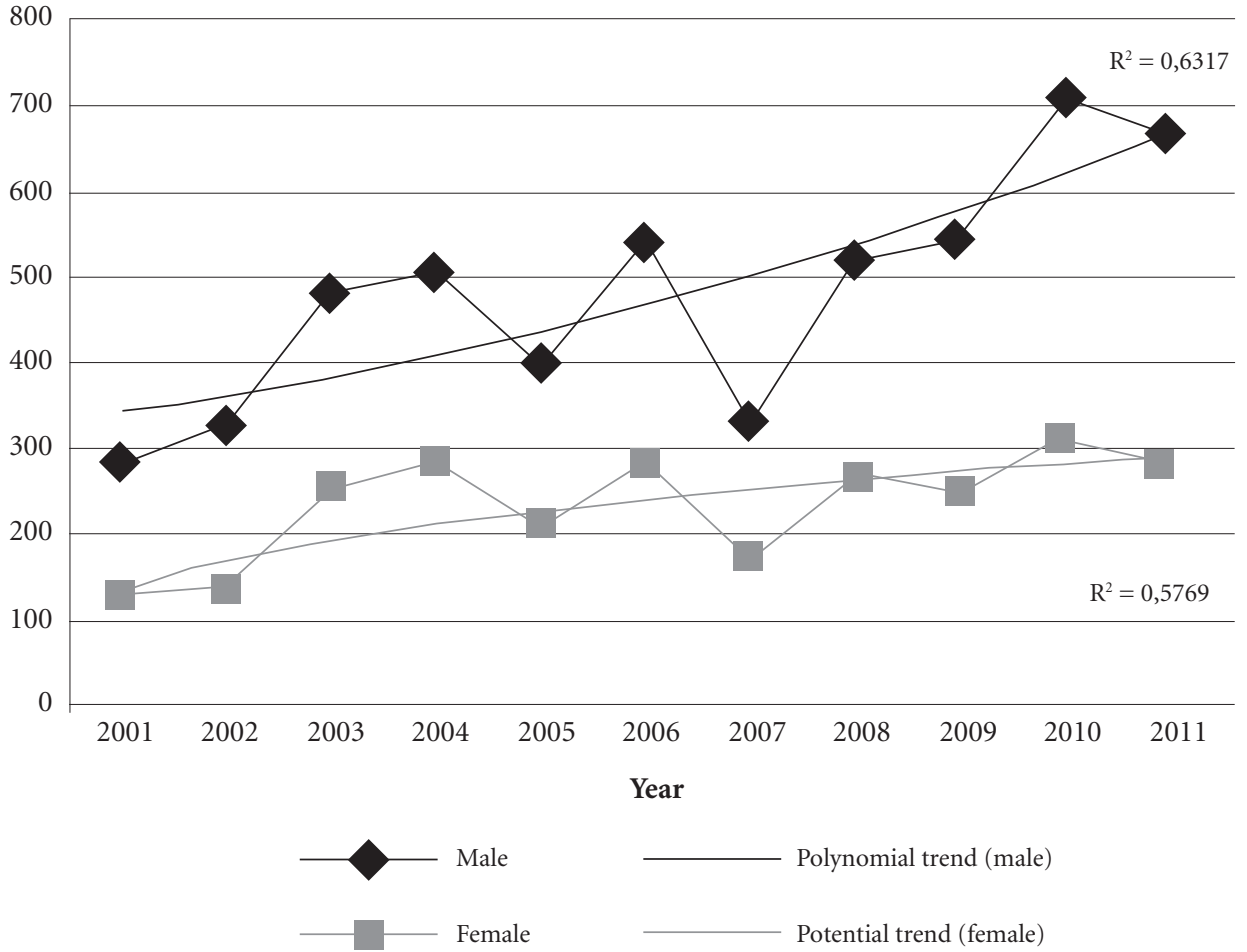

Graph 2. Incidence rate of AIDS by sex, Ceará, Brazil, 2001-2011.

Table 1. Occurrence of Aids per 100,000 population, by age group, and trend value ( $\left.\mathrm{R}^{2}\right)$, Ceará, Brazil, 2001-2011.

\begin{tabular}{lrrrrrrrrrrrl}
\hline Age & $\mathbf{2 0 0 1}$ & $\mathbf{2 0 0 2}$ & $\mathbf{2 0 0 3}$ & $\mathbf{2 0 0 4}$ & $\mathbf{2 0 0 5}$ & $\mathbf{2 0 0 6}$ & $\mathbf{2 0 0 7}$ & $\mathbf{2 0 0 8}$ & $\mathbf{2 0 0 9}$ & $\mathbf{2 0 1 0}$ & $\mathbf{2 0 1 1}$ & \multicolumn{1}{c}{$\mathbf{R}$} \\
\hline $13-19$ & 0.6 & 1 & 1.1 & 0.8 & 1.1 & 1 & 0.3 & 1.5 & 2 & 1.8 & 2.1 & 0.646 (polynomial) \\
$20-24$ & 5.8 & 7.1 & 8.4 & 13.3 & 9 & 12.2 & 5.1 & 8.3 & 8.9 & 12.6 & 13.2 & 0.251 (logarithmic) \\
$25-29$ & 11.8 & 14.8 & 23.2 & 26.4 & 16.2 & 25.4 & 13.1 & 19.1 & 14.6 & 24 & 21.1 & 0.525 (linear) \\
$30-34$ & 18 & 19.2 & 27.8 & 27.6 & 19.4 & 27.4 & 19.1 & 25.6 & 24.2 & 29.6 & 26.8 & 0.310 (potential) \\
$35-39$ & 16.7 & 17.5 & 24.8 & 29.3 & 20.8 & 27.8 & 17.1 & 24.8 & 21.5 & 29 & 23.5 & 0.250 (potential) \\
$40-49$ & 11.7 & 11.5 & 24.1 & 20.4 & 19.4 & 22 & 11.6 & 20 & 22.7 & 23.3 & 21.8 & 0.360 (potential) \\
$50-59$ & 5.9 & 5.8 & 10 & 10.8 & 8.7 & 10.2 & 5.7 & 7.2 & 9.3 & 12.1 & 13.7 & 0.372 (polynomial) \\
60 & 0.9 & 1 & 3.1 & 1.9 & 1.7 & 3.2 & 1.7 & 3.2 & 2.9 & 4.2 & 1.7 & 0.476 (potential) \\
\hline
\end{tabular}

In the period under study growth was linear in the age range $25-29$, with $\mathrm{R} 2=0.525$.

The highest rate of occurrence was in the age groups 30 to 34 and 35 to 39 . Among young people (in the 13-19 age group) notifications of cases grew from less than one case per 100,000 population, in 2001, to 2.1 in 2011. Among the elderly (above age 60), there was a peak in 2010 (4.2 cases per 100,000), which was approximately five times the rate of occurrence in 2001 (Table 1).
Among people in the 13-29 age group, occurrence of AIDS was greater among females than males, and the difference between the sexes was statistically significant $(\mathrm{p}<0.01)$. Among people of adult age and the elderly, occurrence continues to be greater among males (Graphic 3). In terms of distribution by race, the majority ( $80 \%)$ of cases were in people of mixed race ("pardo" in the Portuguese), followed by white, and then black, individuals. Those described as Asian or 
indigenous South Americans had the lowest proportion of cases of AIDS in the period (Table 2).

\section{Discussion}

In other studies, the literature has pointed to secondary data, ecological studies and gaps in the historical series as limiting quality of records, and weakness of explanatory hypotheses at the individual level ${ }^{6-8}$. In the present work, due to the scale of the epidemiological indicators used, neither the analyses nor the contraposition of information between variables have suffered as the result of the lack of some information.

Accompanying the trend in the Northeast, in the state of Ceará the rate of occurrence doubled during the period, although it remained below the figures for the whole of Brazil. In the Northeast, the rate of occurrence of AIDS has grown vertiginously in comparison to other regions of the country. Although the largest proportion of notification of AIDS is in the Brazilian Southeast, the proportion of occurrence in the Northeastern region of the country doubled over 10 years (2001 to 2011) ${ }^{9}$.

As can be seen, AIDS in Ceará does not accompany the overall Brazilian trend of increasing its occurrence in women, in spite of the acceleration of growth, and in this Ceará is similar to the state of Santa Catarina ${ }^{10}$. In Brazil there is an increase in the occurrence of AIDS among women, associated with greater transmission through heterosexual contact, and also progressive incursion of the disease among the poor, with expansion to regions further away from the large metropolitan centers ${ }^{11}$.

Studies point to male vulnerability in terms of access to actions for prevention and promotion of health, increasing the risk of infection by

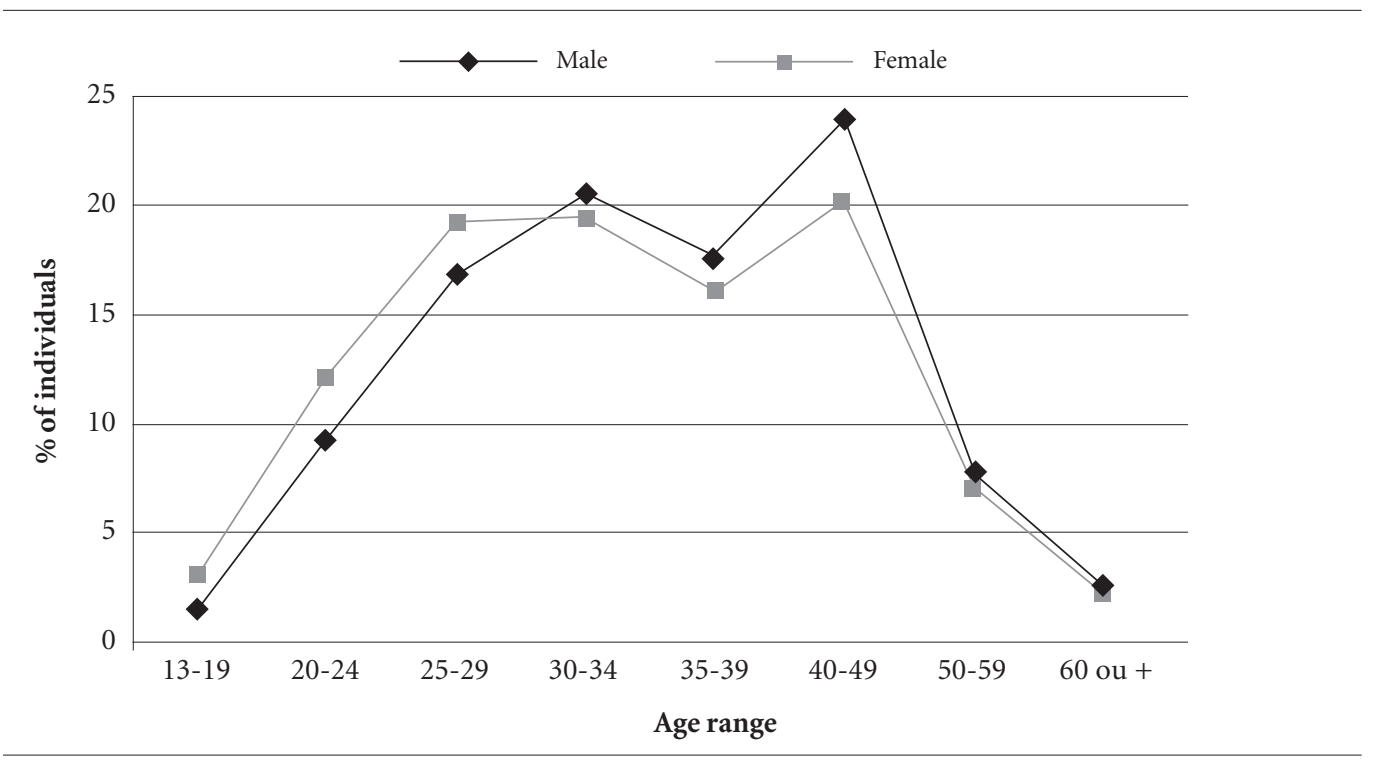

Graph 3. Distribution of cases of AIDS by sex and age, Ceará, Brazil, 2001-2011.

Table 2. Percentage of cases of Aids by race, Ceará, Brazil, 2001-2011.

\begin{tabular}{lrrrrrrrrrrr}
\hline \multicolumn{1}{c}{ Race } & $\mathbf{2 0 0 1}$ & $\mathbf{2 0 0 2}$ & $\mathbf{2 0 0 3}$ & $\mathbf{2 0 0 4}$ & $\mathbf{2 0 0 5}$ & $\mathbf{2 0 0 6}$ & $\mathbf{2 0 0 7}$ & $\mathbf{2 0 0 8}$ & $\mathbf{2 0 0 9}$ & $\mathbf{2 0 1 0}$ & $\mathbf{2 0 1 1}$ \\
\hline Mixed $^{*}$ & 87.5 & 97.8 & $\mathbf{7 6 . 8}$ & 60.3 & 81.3 & 86.1 & 86.5 & 88.4 & 85.6 & 83.7 & 84.7 \\
White & 6.2 & 6.1 & 16 & 30.3 & 14 & 10.3 & 9.5 & 7.9 & 9.7 & 10.2 & 9.8 \\
Black & 0 & 2 & 6.2 & 7.9 & 4.5 & 3.3 & 3.5 & 3.2 & 4.1 & 4.7 & 4.4 \\
Asian & 0 & 0 & 1 & 1.3 & 0.2 & 0.1 & 0.4 & 0.2 & 0.4 & 0.7 & 0.9 \\
Indigenous & 6.2 & 0 & 0 & 0.3 & 0 & 0.1 & 0 & 0.3 & 0.3 & 0.6 & 0.2
\end{tabular}

"Mixed race ("pardo") 
HIV/AIDS. The male population has difficulty in access to healthcare, diagnostic tests and drug therapies, because they are not seen as primary users of the health services ${ }^{12,13}$.

However, male individuals report sexual relations at a precocious age, as well as having more sexual partners and more occasional relationships than women, which tends to lead them into a category of risk behaviors, and delay in diagnosis of serious diseases ${ }^{14}$. As observed in the survey, the average age of diagnosis of AIDS is higher among men than women, that is to say diagnosis has occurred later in the masculine population.

In terms of age, a highlight is the increase in cases of the disease among adolescents and young adults, especially females. The ratio between the sexes, among adolescents, has diminished. In people of age 15 to 24 an inversion of the ratio between the sexes took place over the years 2000-2004, reaching 0.9 cases in males for each case notified in a female ${ }^{2}$.

Young individuals tend to have sexual experiences without the means of prevention and protection of their health and wellbeing ${ }^{12}$. Also, few health units offer individual assistance in sexual and reproductive health to adolescents with HIV that obey the principles of privacy and confidentiality ${ }^{15}$.

The situation is exacerbated by the high indices of advanced immune deficiency among adolescents who have been infected via sexual contract ${ }^{16}$. To the fact of the young person having acquired HIV/AIDS is added the severity with which the virus manifests itself when contagion is by sex at a young age.

Also on the subject of precocious diagnosis in females, a study in the shantytowns ('favelas') of Rio de Janeiro found that young females start sexual activity due to perception of a need to adapt to society ${ }^{17}$.

In spite of the increased incidence of AIDS among young people in Ceará, occurrence of the disease among adults, above all in the 30-39 age range, continues to be in line with the figures for the country3. From 1983 to 2012, people in the
20-49 age range accounted for more than $80 \%$ of the notifications in the state of Ceará ${ }^{4}$. In other words the disease has affected economically active individuals, pointing to AIDS also being a problem of the other economic and social sectors of the country. Men who work, and live with HIV, suffer situations of prejudice, fear of discovery of the disease, as well as the treatment interfering with their work performance and generating a risk of dismissal ${ }^{18}$.

The study indicates the highest rates, in Ceará, over the period studied, as being in the black/white mixed-race population, followed by white people. Similar rates of occurrence can be found in the Center-West Region of Brazil ${ }^{19}$; on the other hand, in the state of Santa Catarina, the highest rate was among white people, since the population profile of that state is more predominantly white? ${ }^{9}$ It is important to consider the difficulties of defining ethnic groups in a highly mixed-race country such as Brazil. However, the racial question becomes important because, as systematic review reveals, almost half of the investigations carried out point to the relationship between inequalities in social-economic indicators and in ethnic-racial group ${ }^{20}$.

According to the 2010 Census, the majority of people in Ceará state themselves to be mixedrace (black/white), or white - respectively $61.9 \%$ and $32 \%$ of the state's population. The data are similar for ethnic groups across Brazil as a whole, in which white and mixed-race (black/white) together comprise more than $90 \%$ of all Brazilians $^{21}$. This pattern would be in line with the greater occurrence of AIDS in the state of Ceará in people from one of these two racial groups.

The study indicates that over time, AIDS in Ceará can be characterized as being primarily a disease of young males, mostly of black/white mixed race; and that there is a trend for rates of occurrence to increase as the years go by. Creation of a program of prevention of AIDS, or improvement of existing programs, focused on these specific populations, with the aim of diminishing these rates, is suggested. 


\section{Collaborations}

SS Paiva, MTG Galvão and RLF Almeida worked in the design, drafting and approval of the article. ER Holanda, LRFS Kerr and NL Pedrosa worked in the writing of the article.

\section{Referências}

1. Joint United Nations Programme on HIV/Aids. Global AIDS response progress reporting 2013: Construction of core indicators for monitoring the 2011 UN Political Declaration on HIV/AIDS. Genebra: WHO; 2013.

2. Szwarcwald CL, Castilho EA. A epidemia de HIV/ AIDS no Brasil: três décadas. Cad Saude Publica 2011; 27(Supl.1):4-5.

3. Brasil. Ministério da Saúde (MS). Boletim epidemiológico: Aids e DST. Ano II - no $01-01^{a}$ a $26^{a}$ semanas epidemiológicas - janeiro a dezembro de 2013. Brasília: MS; 2013.

4. Ceará. Secretaria de Saúde (SESA). Informe Epidemiológico. Fortaleza: SESA; 2013.

5. Teixeira TRA, Gracie R, Malta MS, Bastos FI. Social geography of AIDS in Brazil: identifying patterns of regional inequalities. Cad Saude Publica 2014; 30(2):259271.

6. Gonçalves VF, Kerr LRFS, Mota RMS, Mota JMA. Estimativa de subnotificação de casos de AIDS em uma capital do Nordeste. Rev bras epidemiol 2008; 11(3):356364.

7. Duarte EC, Garcia LP, Freitas LRS, Mansano NH, Monteiro RA, Ramalho WM. Associação ecológica entre características dos municípios e o risco de homicídios em homens adultos de 20-39 anos de idade no Brasil, 1999-2010. Cien Saude Colet 2012; 17(9): 2259-2268.

8. Peres MFT, Almeida JF, Vicentin D, Ruotti C, Nery MB, Cerda M. Evolução dos homicídios e indicadores de segurança pública no Município de São Paulo entre 1996 e 2008: um estudo ecológico de séries temporais. Cien Saude Colet 2012; 17(12):3249-3257.

9. Brasil. Ministério da Saúde (MS). Boletim epidemiológico: Aids e DST. Versão Preliminar. Ano IX - $\mathrm{n}^{\mathrm{o}} 01-01^{\mathrm{a}}$ a 26a semanas epidemiológicas - junho de 2012. Brasília: MS; 2012.

10. Schuelter-Trevisol F, Pucci P, Justino AZ, Pucci N, Silva ACB. Perfil epidemiológico dos pacientes com HIV atendidos no sul do Estado de Santa Catarina, Brasil, em 2010. Epidemiol Serv Saude 2013; 22(1):87-94.

11. Maliska ICA, Padilha MICS, Vieira M, Bastiani J. Percepções e significados do diagnóstico e convívio com o HIV/AIDS. Rev gauch enferm 2009; 30(1):85-91.

12. Marques Junior JS, Gomes R, Nascimento EF. Masculinidade hegemônica, vulnerabilidade e prevenção ao HIV/AIDS. Cien Saude Colet 2012; 17(2):511-520.

13. Brasil. Ministério da Saúde (MS). Politica Nacional de Atenção Integral à Saúde do Homem. Brasília: MS; 2008.

14. Couto MCPP, Prati LE, Koller SH. Características sociocomportamentais de homens e mulheres portadores de HIV/AIDS com 50 anos ou mais do sul do Brasil. Rev psicol saúde 2012; 4(2):143-151.

15. Taquette SR, Matos HJ, Rodrigues AO, Bortolotti LR, Amorim E. A epidemia de AIDS em adolescentes de 13 a 19 anos, no município do Rio de Janeiro: descrição espaço-temporal. Rev Soc Bras Med Trop 2011; 44(4):467-470.

16. Cruz MLS, Hance LF, Korelitz J, Aguilar A, Byrne J, Serchuk LK, Hazra R, Worrel C. Characteristics of HIV Infected Adolescents in Latin America: Results from the NISDI Pediatric Study. J Trop Pediatr 2011; 57(3):165172. 
17. Taquette SR, Meirelles ZV. Convenções de gênero e sexualidade na vulnerabilidade às DSTs/AIDS de adolescentes femininas. Adolesc Saude 2012; 9(3):56-64.

18. Freitas JG, Galvão MTG, Araujo MFM, Costa E, Lima ICV. Coping experiences in the work enviroment of men living with HIV/AIDS. Rev Esc Enferm USP 2012; 46(3):720-726.

19. Pereira JA, Marques RH, Fonseca LVL, Eleutério AM, Bonfim MLC, Dias OV. Infecção pelo HIV e AIDS em município do norte de Minas Gerais. Revista de APS 2011; 14(1):39-49.

20. Kabad JF, Bastos JL, Santos RV. Raça, cor e etnia em estudos epidemiológicos sobre populações brasileiras: revisão sistemática na base PubMed. Physis 2012; 22(3):895-918.

21. Instituto Brasileiro de Geografia e Estatística (IBGE). Base de Informações do Censo Demográfico 2010: resultados do Universo por setor censitário. Rio de Janeiro: MPOG; 2011.

Article submitted 05/26/2014

Approved 07/23/2014

Final version submitted 08/11/2014 